\title{
SELEKSI DAN PEROLEHAN GENETIK PADA UJI KETURUNAN GENERASI KEDUA KAYUPUTIH (Melaleuca cajuputi subsp. cajuputi) DI GUNUNGKIDUL
}

Selection and genetic gain observed at second generation progeny trial of cajuput (Melaleuca cajuputi subsp. cajuputi) in Gunungkidul

\author{
Sumardi, Noor Khomsah Kartikawati, Prastyono dan Anto Rimbawanto \\ Balai Besar Penelitian dan Pengembangan Bioteknologi dan Pemuliaan Tanaman Hutan \\ Jl. Palagan Tentara Pelajar Km.15, Purwobinangun, Pakem, Sleman, Yogyakarta \\ email: sumardi_184@yahoo.com
}

Tanggal diterima: 16 Juni 2017, Tanggal direvisi: 9 Agustus 2017, Disetujui terbit: 30 Mei 2018

\begin{abstract}
Breeding for cajuput in Indonesia has moved into advanced generation breeding cycle through establishing second-generation progeny trial. A series of selection would be practiced in the trial before converting into a seedling seed orchard to produce genetically improved seed. In this study, a series of selection, followed by prediction of genetic gain will be observed in the second-generation progeny trial of cajuput established at Gunungkidul. The trial was laid out in randomized complete block design (RCBD), 65 families, three tree-plot, four replications, and spacing of $3 \times 1,5$ meter. Measurement was conducted on height and diameter at 24 months age. In the trial, within-plot selection has been practiced phenotypicaly by retaining one of the best tree out of the three tree within each plot. Succesive family selection was then simulated from the result of withinplot selection. Results of study showed that estimates of heritabily for diameter were higher than that for height. Genetic and phenotypic correlation between the two traits was moderate at around 0.57. Within-plot selection practiced in the trial resulted positive selection differential for all measured traits. Diameter showed higher coefficient weight of selection (0.4280) than height (0.0406) which indicates that the practiced within-plot selection was more imposed for diameter than that for height. Genetic gain from within-plot selection calculated using selection index were $20.76 \%$ for diameter and $12.73 \%$ for height. Simulated family selection using the same coefficient weight as within-plot selection resulted lower genetic gain at around $12.26 \%$ and $7.52 \%$ for diameter and height, respectivelly.
\end{abstract}

Keywords: selection index, within-plot selection, family selection, genetic parameter, coefficient of weight

\begin{abstract}
ABSTRAK
Pemuliaan kayuputih di Indonesia mulai memasuki pada pemuliaan generasi tingkat lanjut dengan dibangunnya uji keturunan generasi kedua. Serangkaian kegiatan seleksi akan dilakukan pada plot uji keturunan sebelum dikonversi menjadi kebun benih untuk menghasilkan benih unggul. Pada penelitian ini serangkaian kegiatan seleksi dan prediksi perolehan genetik akan dilakukan pada plot uji keturunan generasi kedua kayuputih di Gunungkidul. Plot uji dibangun dengan menggunakan rancangan acak lengkap berblok (RALB), 65 famili, tiga tree-plot, empat ulangan, dan jarak tanam $3 \times 1,5$ meter. Pengukuran tinggi dan diameter dilakukan pada tanaman umur 24 bulan. Pada plot uji keturunan ini, seleksi dalam plot telah dilakukan secara fenotipik dengan mempertahankan salah satu pohon terbaik dari tiga pohon dalam setiap plot. Seleksi famili selanjutnya disimulasikan dari hasil seleksi dalam plot. Hasil penelitian menunjukkan bahwa estimasi heritabilitas sifat diameter lebih tinggi daripada sifat tinggi. Korelasi genetik dan fenotipik antara dua sifat tersebut termasuk sedang $(0,57)$. Seleksi dalam plot yang telah dilakukan menghasilkan diferensial seleksi positif untuk semua sifat yang diukur. Sifat diameter menunjukkan koefisien bobot seleksi yang lebih tinggi $(0,4280)$ daripada sifat tinggi $(0,0406)$, yang menunjukkan bahwa seleksi dalam plot lebih diprioritaskan pada sifat diameter. Perolehan genetik hasil seleksi dalam plot yang dihitung menggunakan indeks seleksi adalah sebesar $20,76 \%$ untuk diameter dan 12,73\% untuk tinggi. Simulasi seleksi famili menggunakan koefisien bobot yang sama seperti pada seleksi dalam plot menghasilkan perolehan genetik lebih rendah yaitu 12,26\% (diameter) dan 7,52\% (tinggi).
\end{abstract}

Kata kunci: indek seleksi, seleksi dalam plot, seleksi famili, parameter genetik, koefisien bobot

\section{PENDAHULUAN}

Kayuputih (Melaleuca cajuputi subsp. cajuputi) merupakan salah satu jenis tanaman yang menghasilkan minyak atsiri dari hasil penyulingan daunnya, yang dimanfaatkan oleh industri minyak kayuputih sebagai bahan dasar pembuatan obat gosok untuk penghangat dan 
aroma terapi (Kartikawati, Na'iem, Hardiyanto, \& Rimbawanto, 2013). Indonesia sebagai konsumen sekaligus produsen minyak kayuputih belum mampu mencukupi kebutuhan nasionalnya sebanyak 1.500 ton per tahun, sehingga terpaksa harus melakukan impor minyak eucalyptus dari RRC sebagai substitusi (Kartikawati, Rimbawanto, Susanto, Baskorowati, \& Prastyono, 2014). Oleh karena itu untuk mendukung pemenuhan kebutuhan minyak kayuputih nasional perlu dilakukan perluasan dan pemuliaan tanaman untuk meningkatkan rendemen dan kualitas minyak.

Upaya pemuliaan tanaman kayuputih telah dimulai dengan membangun kebun benih uji keturunan skala kecil pada tahun 1998 di Paliyan Kabupaten Gunungkidul dengan menggunakan 19 famili yang berasal dari Kepulauan Buru, Ambon, Seram, dan Australia bagian barat dan utara (Kartikawati \& Sumardi, 2017). Untuk memperluas basis genetiknya pada tahun 2002 dibangun kebun benih uji keturunan generasi pertama (F1) di Gundih, Ponorogo dan Cepu (Kartikawati et al., 2014). Upaya peningkatan kualitas genetik kayuputih berlanjut pada pembangunan plot uji keturunan generasi kedua (F2) pada tahun 2008 dengan materi genetik berasal dari pohon plus kebun benih F1 dan beberapa famili hasil persilangan terkendali (Kartikawati et al., 2014).

Pembangunan plot uji keturunan selain dimanfaatkan sebagai populasi pengujian genetik untuk mengetahui parameter genetik, juga akan digunakan sebagai populasi penghasil benih unggul (Zobel \& Talbert, 1984). Plot uji keturunan dapat digunakan sebagai populasi penghasil benih unggul setelah melalui serangkaian penjarangan seleksi berdasarkan parameter genetik (Handayani, Sunarti, \& Nirsatmanto, 2017). Proses seleksi yang dilakukan akan diarahkan untuk mendapatkan perolehan genetik yang optimal dan mencegah kemungkinan terjadinya kehilangan potensi perolehan genetik (loss potential genetic gain) (Surip, Indrioko, Nirsatmanto, \& Setyaji, 2017). Pada program pemuliaan generasi tingkat lanjut (advanced generation breeding program), perolehan genetik secara akumulatif dihitung berdasarkan jumlah perolehan genetik dari setiap generasi pemuliaan yang dilampaui (Handayani et al., 2017).

Walaupun pemuliaan kayuputih sudah memasuki generasi kedua (Kartikawati et al., 2014), informasi seleksi dan perolehan genetiknya belum pernah dilaporkan. Untuk itu penelitian ini dilaksanakan dengan tujuan mengetahui informasi parameter genetik dan seleksi serta pengaruhnya terhadap perolehan genetik pada uji keturunan F2 kayuputih di Gunungkidul. Hasil penelitian ini diharapkan dapat memberikan manfaat terhadap proses seleksi yang lebih terarah dan konsisten serta mencegah hilangnya potensi genetik dalam pemuliaan kayuputih generasi kedua.

\section{BAHAN DAN METODE}

\section{A. Lokasi penelitian}

Penelitian di lakukan pada plot uji keturunan F2 kayuputih di Petak 93, Playen, Kabupaten Gunungkidul. Lokasi penelitian terletak pada $7^{\circ} 59^{\prime} 10^{\prime \prime}$ - 7 $7^{\circ} 59^{\prime} 42 "$ Lintang Selatan dan $110^{\circ} 30^{\prime} 00^{\prime \prime}$ - $110^{\circ} 30^{\prime} 59^{\prime \prime}$ Bujur Timur. Secara administratif Petak 93 Playen terletak di Desa Banyusoco, Kecamatan Playen, Kabupaten Gunungkidul, Provinsi Daerah Istimewa Yogyakarta. Berdasarkan klasifikasi iklim Schmidt dan Ferguson Petak 93 Playen termasuk tipe iklim C dengan curah hujan 1.894 $\mathrm{mm} /$ tahun yang terjadi pada bulan November hingga Maret (Saputra, 2010). Topografi lokasi penelitian berdasarkan kategori Keputusan Menteri Pertanian No. 837/Kpts/Um/11/1980 dan No. 683/Kpts/Um/8/1981, termasuk dalam kategori datar dengan kelerengan antara $0-8 \%$.

\section{B. Bahan dan alat penelitian}

Bahan penelitian yang digunakan adalah tanaman kayuputih pada plot uji keturunan F2 di Petak 93, Playen umur 24 bulan. Penelitian dilakukan dengan pengukuran tinggi dan diameter tanaman menggunakan galah dan kaliper. Data yang diperoleh ditabulasi 
menggunakan alat tulis dan tally-sheet untuk selanjutnya dianalisis menggunakan alat bantu komputer.

\section{Metode penelitian}

Rancangan penelitian yang digunakan pada plot uji keturunan F2 adalah rancangan acak lengkap berblok (RALB) yang terdiri dari 65 famili, 3 tree-plot dan 4 blok sebagai ulangan serta jarak tanam $3 \times 1,5 \mathrm{~m}$. Sebanyak 65 famili yang diuji tersebut berasal dari 13 famili half sib dari kebun benih F1 di Paliyan; 32 famili half - sib dari kebun benih F1 di Ponorogo, Gundih dan Cepu; 12 famili full- sib dari kebun benih F1 di Ponorogo. Pada plot ini juga digunakan sebanyak 8 famili infusi sebagai kontrol yang terdiri dari 5 famili dari tegakan alam di Ambon, 2 famili dari tegakan di Gundih, dan 1 famili dari tegakan di Ponorogo. Variabel yang diukur pada penelitian ini adalah sifat tinggi dan diameter setinggi dada, dan dilakukan pada bulan Desember tahun 2010. Penjarangan seleksi dalam plot (within-plot selection) telah dilaksanakan di dalam plot uji keturunan dengan membuang dua pohon terjelek dalam setiap plot pada umur 44 bulan.

\section{Analisis data}

\section{Analisis varians dan parameter genetik}

Analisis varians dan kovarians dihitung menggunakan data dari setiap individu pohon dengan model linear:

$\mathrm{Y}_{i j k}=\mu+\mathrm{R}_{i}+\mathrm{F}_{j}+\mathrm{RF}_{i j}+\mathrm{E}_{i j k}$

dimana:

$\mathrm{Y}_{i j k}$ : observasi individu ke- $k$ di dalam ulangan ke- $i$ dan famili ke- $j$,

$\mathrm{F}_{j}$ : pengaruh famili ke- $j$,

$\mathrm{RF}_{i j}$ : pengaruh interaksi blok ke-i dengan famili ke-j, dan

$\mathrm{E}_{i j k}$ : galat

Parameter genetik yang dihitung meliputi heritabilitas, korelasi genetik, dan perolehan genetik. Nilai heritabilitas terbagi menjadi heritabilitas individu dan heritabilitas famili, yang dihitung pada masing-masing sifat dengan menggunakan rumus sebagai berikut (Zobel \& Talbert, 1984):

Heritabilitas individu:

$$
\mathrm{h}_{i}^{2}=3 \times \sigma_{f}^{2} /\left(\sigma_{f}^{2}+\sigma_{f b}^{2}+\sigma_{w}^{2}\right)
$$

dimana:

$\mathrm{h}_{i}^{2} \quad$ : heritabilitas individu

$\sigma_{f}^{2}$ : komponen varians famili

$\sigma_{f b}^{2}:$ komponen varians interaksi antara famili $\times$ blok

$\sigma_{w}^{2}:$ komponen varians dalam plot

Heritabilitas famili:

$$
\mathrm{h}_{f}^{2}=\sigma_{f}^{2} /\left(\sigma_{f}^{2}+\sigma_{f b}{ }^{2} / \mathrm{b}+\sigma_{w}{ }^{2} / \mathrm{nb}\right)
$$

dimana:

$\mathrm{h}_{f}^{2} \quad$ : heritabilitas famili

b : rerata harmonik jumlah blok

$\mathrm{n}$ : rerata harmonik jumlah pohon per plot

Korelasi genetik $\left(\mathrm{r}_{g i j}\right)$ dan fenotipik $\left(\mathrm{r}_{p i j}\right)$ antar varibel yang diamati dihitung dengan menggunakan rumus sebagai berikut (Falconer, 1960):

$$
\begin{aligned}
& \mathrm{r}_{g i j}=\operatorname{cov}_{f(i j)} /\left(\sigma_{f i}{ }^{2} \times \sigma_{f j}{ }^{2}\right)^{1 / 2} \ldots \ldots \\
& \mathrm{r}_{p i j}=\operatorname{cov}_{p(i j)} /\left(\sigma_{p i}{ }^{2} \times \sigma_{p j}{ }^{2}\right)^{1 / 2} .
\end{aligned}
$$

dimana, $\operatorname{cov}_{f(i j)}$ dan $\operatorname{cov}_{p(i j)}$ masing-masing secara berurutan merupakan kovarians famili dan kovarians fenotipik antara sifat ke- $i$ dengan sifat ke-j. Sedangkan $\sigma_{f i}{ }^{2}, \sigma_{f j}{ }^{2}, \sigma_{p i}{ }^{2}$, $\sigma_{p j}^{2}$ masing-masing secara berurutan merupakan komponen varians famili untuk sifat ke- $i$ dan ke- $j$, dan komponen varians fenotipik untuk sifat ke- $i$ dan ke- $j$.

\section{Seleksi dan perolehan genetik}

Seleksi dilaksanakan berdasarkan indeks seleksi yang merupakan gabungan dua sifat sebagai kriteria seleksi, yaitu tinggi dan diameter. Penetapan koefisien bobot masingmasing sifat dan prediksi perolehan genetik dihitung melalui langkah-langkah sebagai berikut (Nirsatmanto \& Kurinobu, 2002):

a. diferensial seleksi $\left(\Delta \mathrm{p}_{w}\right)$ yang dihitung sebagai perbedaan antara satu pohon terbaik setelah penjarangan seleksi di dalam setiap plot terhadap rata-rata populasi awal pada 
masing-masing sifat, kemudian digunakan untuk menurunkan koefisien bobot dalam plot $\left(\mathrm{b}_{w}\right)$ untuk setiap sifat dengan rumus:

$$
\mathrm{b}_{w}=\mathrm{P}_{w}^{-1} \times \Delta \mathrm{p}_{w}
$$

b. prediksi perolehan genetik hasil seleksi dalam plot $\left(\Delta \mathrm{g}_{w}\right)$ dihitung dengan rumus berikut (Yamada, 1977):

$$
\Delta \mathrm{g}_{w}=\mathrm{G}_{w} \times \mathrm{b}
$$

dimana, $\mathrm{G}_{w}$ adalah matrik varians-kovarians genetik dalam plot yang dihitung sebagai $3 / 4$ dari varians dan kovarians genetik aditif,

c. korelasi biserial $\left(\mathrm{r}_{b}\right)$ untuk menilai kecocokan indeks yang diperoleh dengan rumus (6), dihitung dengan menggunakan rumus berikut (Yamada, 1977):

$$
\mathrm{r}_{b}=\left(\mathrm{I}_{s}-\mathrm{I}\right) /\left(\mathrm{I}_{q}-\mathrm{I}\right)
$$

dimana, I adalah nilai indeks rata-rata seluruh populasi, $\mathrm{I}_{s}$ adalah rata-rata nilai indeks dari individu terpilih berdasarkan seleksi aktual pada umur 44 bulan, dan $\mathrm{I}_{q}$ adalah rata-rata nilai indeks dari individu terpilih berdasarkan nilai indeks tertinggi,

d. prediksi perolehan genetik hasil seleksi famili $\left(\Delta \mathrm{g}_{f}\right)$ dihitung dengan rumus sebagai berikut (Hazel, 1943):

$$
\Delta \mathrm{g}_{f}=\mathrm{G}_{f} \times \mathrm{b}_{w} /\left(\mathrm{b}_{w}{ }^{\prime} \times \mathrm{P}_{f} \times \mathrm{b}_{w}\right)^{1 / 2}
$$

dimana, $\mathrm{G}_{f}$ adalah matrik varians-kovarians genetik famili, dan $\mathrm{P}_{f}$ adalah matrik varianskovarians fenotipik.

\section{HASIL DAN PEMBAHASAN}

\section{A. Daya adaptasi dan pertumbuhan tanaman}

Daya adaptasi yang ditunjukkan oleh persen hidup tanaman kayuputih pada plot uji keturunan F2 di Gunungkidul sampai dengan umur 24 bulan relatif cukup baik. Hal tersebut terlihat dari rata-rata persen hidup tanaman secara keseluruhan sebesar $77,44 \%$. Beberapa blok tanaman uji terdiri dari famili yang tidak lengkap sebagai akibat kematian seluruh individu pohon dalam satu plot pada beberapa famili: pada blok 1 sebanyak 2 famili, blok 2 sebanyak 5 famili, blok 3 sebanyak 2 famili.
Berdasarkan data jumlah individu dalam plot (3 pohon per plot), rata-rata persen hidup tanaman di dalam plot sebesar $72,33 \%$ atau ratarata jumlah tanaman yang hidup di dalam setiap plot sebanyak 2,17 tanaman. Persen hidup tanaman kayuputih pada plot uji sebagaimana disampaikan di atas menunjukkan bahwa daya adaptasi tanaman kayuputih di lokasi tersebut cukup tinggi pada lokasi tanah yang relatif kurang subur dengan curah hujan 1.894 $\mathrm{mm} /$ tahun (Saputra, 2010). Tingginya persen hidup tanaman uji kemungkinan disebabkan oleh sifat tanaman kayuputih yang dapat beradaptasi pada kondisi lahan yang bervariasi. Kayuputih mampu beradaptasi dengan baik pada dataran rendah hingga tinggi dan pada kondisi tanah subur hingga marginal (Mawaddah, Mansur, \& Saria, 2012). Persen hidup tanaman kayuputih uji keturunan di Gunungkidul tersebut lebih tinggi dibanding dengan persen hidup tanaman kayuputih uji keturunan di Pulau Timor, Nusa Tenggara Timur pada umur yang sama yaitu sebesar $60 \%$ (Sumardi, 2017).

Berdasarkan data persen hidup tanaman pada plot uji keturunan F2 kayuputih di Gunungkidul, maka kondisi tanaman tersebut secara umum layak dan memenuhi syarat teknis untuk digunakan sebagai obyek penelitian yang berkaitan dengan seleksi pohon dalam plot dan seleksi famili. Penelitian yang melibatkan tindakan seleksi pohon dalam plot dan seleksi famili menghendaki adanya persen hidup tanaman tinggi. Hal ini disebabkan karena persen hidup tanaman menjadi faktor penting dalam tindakan pemuliaan tanaman untuk menjaga validitas analisis data (Chambers \& Borralho, 1997).

Selain persen hidup tanaman, data pertumbuhan tinggi dan diameter tanaman kayuputih pada plot uji juga menunjukkan tingkat pertumbuhan yang baik. Data pertumbuhan tanaman berupa tinggi dan diameter tanaman disajikan pada Tabel 1 . Secara umum laju pertumbuhan diameter tanaman lebih cepat dibanding dengan laju 
Seleksi dan Perolehan Genetik pada Uji Keturunan Generasi Kedua Kayuputih (Melaleuca cajuputi subsp. cajuputi) di Gunungkidul Sumardi, Noor Khomsah Kartikawati, Prastyono, dan Anto Rimbawanto

pertumbuhan tinggi tanaman. Habitus asli tanaman kayuputih yang cenderung bercabang banyak dan bertajuk tebal cenderung memacu pertumbuhan diameter lebih dominan.

Tabel 1. Pertumbuhan tinggi dan diameter tanaman kayuputih pada plot uji keturunan F2 umur 24 bulan di Gunungkidul, Yogyakarta

\begin{tabular}{lcc}
\hline \multicolumn{1}{c}{ Parameter } & Tinggi $(\mathrm{m})$ & Diameter $(\mathrm{cm})$ \\
\hline Rata-rata & 2,83 & 3,10 \\
Maksimal & 4,81 & 7,06 \\
Minimal & 0,15 & 0,10 \\
Standar deviasi & 1,80 & 1,51 \\
Koefisien variasi & 16,71 & 20,83 \\
\hline
\end{tabular}

Perbedaan laju pertumbuhan tinggi dan diameter tanaman uji keturunan F2 kayuputih di Gunungkidul tersebut juga terlihat dari tingkat variasi fenotipiknya. Koefisien variasi diameter terlihat lebih besar jika dibandingkan dengan koefisien variasi tinggi tanaman (Tabel 1). Namun demikian, secara umum variasi fenotipik tanaman menunjukkan bahwa tanaman kayuputih pada plot uji keturunan tersebut masih memiliki pertumbuhan tanaman yang normal sebagaimana habitus tanaman aslinya. Sebagai perbandingan data pertumbuhan tanaman uji keturunan kayuputih di Pulau Timor pada umur yang sama menunjukkan rerata tinggi tanaman sebesar $1,13 \mathrm{~m}$ dan diameter sebesar 0,77 cm (Sumardi, 2017).
Kondisi lahan kurang subur pada lokasi penelitian di Gunungkidul diduga tidak memberikan dampak buruk pada normalitas pertumbuhan tanaman kayuputih.

\section{B. Heritabilitas dan korelasi genetik}

Nilai heritabilitas digunakan untuk mengetahui proporsi faktor genetik yang diturunkan dari induk kepada keturunannya (Zobel \& Talbert, 1984). Komponen varians dan estimasi nilai heritabilitas pada plot uji keturunan F2 kayuputih disajikan pada Tabel 2. Komponen varians famili sifat diameter lebih tinggi dibanding sifat tinggi, sedangkan komponen varians interaksi dan komponen varians dalam plot sifat diameter lebih rendah dibanding sifat tinggi. Proporsi nilai komponen varians tersebut akan memberikan pengaruh positif terhadap nilai heritabilitas. Sebagaimana dilaporkan oleh Handayani et al., (2017) bahwa perbedaan proporsi nilai komponen varians dalam plot terhadap komponen varians famili akan memberikan dampak pada perbedaan estimasi nilai heritabilitas. Semakin besar nilai komponen varians famili yang diikuti dengan semakin rendahnya komponen varians interaksi dan komponen varians dalam plot akan menghasilkan nilai heritabilitas semakin besar. Taksiran nilai heritabilitas merupakan rasio perbandingan antara varian aditif terhadap total varian fenotipik (Li et al., 2016).

Tabel 2. Nilai komponen varians, heritabilitas individu $\left(\mathrm{h}_{i}^{2}\right)$ dan heritabilitas famili $\left(\mathrm{h}_{f}^{2}\right)$ pada plot uji keturunan F2 kayuputih umur 24 bulan di Gunungkidul, Yogyakarta

\begin{tabular}{|c|c|c|c|c|c|}
\hline \multirow{2}{*}{ Sifat } & \multicolumn{3}{|c|}{ Komponen varians } & \multirow{2}{*}{$\mathrm{h}_{i}^{2}$} & \multirow{2}{*}{$\mathrm{h}_{f}^{2}$} \\
\hline & Famili & Famili $\times$ blok & Dalam plot & & \\
\hline Tinggi & $\begin{array}{c}0,2214 \\
(6,86 \%)\end{array}$ & $\begin{array}{c}0,4382 \\
(13,58 \%)\end{array}$ & $\begin{array}{c}2,5677 \\
(79,56 \%)\end{array}$ & 0,2058 & 0,3576 \\
\hline Diameter & $\begin{array}{c}0,2796 \\
(12,70 \%)\end{array}$ & $\begin{array}{c}0,2418 \\
(10,99 \%)\end{array}$ & $\begin{array}{c}1,6797 \\
(76,31 \%)\end{array}$ & 0,3810 & 0,5301 \\
\hline
\end{tabular}

Keterangan: Angka dalam kurung adalah proporsi (\%) komponen varians terhadap total fenotipik varians

Nilai heritabilitas individu untuk sifat diameter lebih besar dibanding sifat tinggi, dimana sifat diameter memiliki perbedaan proporsi antara varians dalam plot terhadap varians famili lebih kecil dibanding sifat tinggi.
Besarnya nilai heritabilitas individu tersebut memberikan indikasi bahwa seleksi dalam plot berdasarkan sifat diameter berpotensi memberikan perolehan genetik yang lebih besar. Namun demikian pada seleksi multi sifat 
melalui indeks seleksi sebagaimana dilaksanakan dalam penelitian ini, besarnya dampak seleksi terhadap perolehan genetik juga akan ditentukan oleh korelasi genetik serta nilai koefisien bobot antarsifat yang dijadikan sebagai kriteria seleksi.

Nilai heritabilitas famili menunjukkan nilai yang lebih besar dibanding heritabilitas individu pada semua sifat. Namun demikian, berdasarkan tingkat kategorinya nilai heritabilitas famili lebih rendah dibanding heritabilitas individu. Nilai heritabilitas famili termasuk kategori rendah - sedang $(0,3576$ 0,5301), sedangkan nilai heritabilitas individu termasuk kategori sedang - tinggi (0,2058 0,3810). Kedua nilai heritabilitas ini akan memberikan dampak pada peningkatan perolehan genetik akumulatif di dalam plot uji keturunan F2 kayuputih. Hal ini karena plot uji keturunan dibangun dengan menggunakan 3 tree-plot dan 4 blok ulangan dan kegiatan seleksi secara bertahap akan dilakukan melalui seleksi dalam famili dan seleksi antar famili.

Disamping nilai heritabilitas, seleksi dalam plot uji keturunan juga akan dipengaruhi oleh korelasi genetik antarsifat. Korelasi genetik digunakan untuk mengetahui kedekatan hubungan genetik antara sifat. Nilai tersebut berperan dalam menentukan prediksi pengaruh dan efektifitas seleksi suatu sifat (Gaspar, Louzada, Aguiar, \& Almeida, 2008). Korelasi genetik dan korelasi fenotipik antarsifat pada plot uji keturunan F2 kayuputih disajikan pada Tabel 3. Nilai korelasi fenotipik antarsifat pada penelitian ini yang merupakan nilai korelasi fenotipik rata-rata famili memberikan angka yang positif.

Tabel 3. Korelasi genetik dan fenotipik antara sifat diameter dan tinggi pada plot uji keturunan F2 kayuputih umur 24 bulan di Gunungkidul

\begin{tabular}{lcc}
\hline \multicolumn{1}{c}{ Sifat } & Tinggi & Diameter \\
\hline Tinggi & - & 0,57 \\
Diameter & 0,57 & - \\
\hline
\end{tabular}

Keterangan: korelasi fenotipik (di atas diagonal), korelasi genetik (di bawah diagonal)
Korelasi genetik dan korelasi fenotipik antara kedua sifat yakni diameter dengan tinggi memiliki nilai yang sama, dan menunjukkan korelasi antara kedua sifat yang tidak terlalu kuat. Hal ini memberikan indikasi bahwa kedua sifat yang diamati, yaitu tinggi dan diameter, perlu digunakan secara bersama-sama sebagai kriteria seleksi. Namun demikian mengingat seleksi yang dilakukan pada plot uji keturunan F2 kayuputih ini adalah menggunakan indeks seleksi, maka penentuan koefisien bobot masing-masing sifat perlu ditetapkan secara lebih cermat agar nilai perolehan genetiknya lebih terarah dan sesuai dengan target produktivitas dan keunggulan yang diharapkan.

\section{Seleksi dan perolehan genetik}

\section{Seleksi dalam plot}

Seleksi dalam plot merupakan kegiatan penjarangan seleksi yang pertama kali dilaksanakan pada plot uji keturunan F2 kayuputih. Selanjutnya penerapan indeks seleksi pada penelitian ini dilakukan berdasarkan hasil penjarangan seleksi dalam plot tersebut, yaitu dengan menyisakan 1 individu terbaik dari 3 individu di dalam setiap plot secara fenotipik. Diferensial seleksi, koefisien bobot dan prediksi perolehan genetik sebagai hasil seleksi dalam plot disajikan pada Tabel 4. Hasil seleksi melalui seleksi 1 individu pohon terbaik dalam setiap plot memberikan nilai diferensial seleksi positif pada kedua sifat yang diamati. Hal ini menunjukkan bahwa seleksi dalam plot sudah dilaksanakan sesuai dengan arah target produktivitas yang diharapkan.

Hasil seleksi dalam plot juga menunjukkan bahwa sifat diameter memiliki koefisien bobot jauh lebih besar, yakni sepuluh kali lipat dibanding sifat tinggi (Tabel 4). Hal ini memberikan indikasi bahwa seleksi dalam plot yang dilaksanakan secara fenotipik pada plot uji keturunan F2 kayuputih di Gunungkidul tersebut lebih ditekankan pada sifat diameter daripada sifat tinggi. Pola seleksi ini sejalan dengan tujuan pemuliaan kayuputih dimana dengan meningkatkan sifat diameter cenderung 
akan mempengaruhi jumlah percabangan kayuputih yang dihasilkan untuk produksi biomassa daun. Semakin besar diameter maka akan memicu semakin banyak percabangan yang dimiliki. Percabangan yang banyak akan menghasilkan biomassa daun yang semakin tinggi dan pada akhirnya akan berdampak pada peningkatan produksi minyak kayuputihnya.

Tabel 4. Hasil penerapan indeks seleksi untuk seleksi dalam plot dan seleksi famili pada plot uji keturunan F2 kayuputih umur 24 bulan di Gunungkidul

\begin{tabular}{cccccc}
\hline \multirow{2}{*}{ Sifat } & \multicolumn{3}{c}{ Seleksi dalam plot } & & Seleksi famii \\
\cline { 2 - 3 } & $\begin{array}{c}\text { Diferensial } \\
\text { seleksi }\end{array}$ & $\begin{array}{c}\text { Koefisien } \\
\text { bobot }\end{array}$ & $\begin{array}{c}\text { Perolehan genetik } \\
(\%)\end{array}$ & & $\begin{array}{c}\text { Perolehan genetik } \\
(\%)\end{array}$ \\
Tinggi & $\mathrm{r}_{b}=0,585^{\mathrm{a}}$ & & & \\
Diameter & 0,4799 & 0,0406 & 12,73 & & 7,52 \\
& 0,7546 & 0,4280 & 20,76 & & 12,26 \\
\hline
\end{tabular}

Keterangan: ${ }^{a}$ merupakan koefisien korelasi biserial

Nilai estimasi perolehan genetik hasil seleksi dalam plot untuk sifat diameter dua kali lipat lebih tinggi dibanding dengan sifat tinggi (Tabel 4). Tingginya nilai perolehan genetik sifat diameter merupakan dampak dari tingginya nilai heritabilitas (Tabel 1) dan diferensial seleksi, serta cerminan dari koefisien bobot yang digunakan pada seleksi untuk sifat tersebut. Besarnya nilai perolehan genetik hasil seleksi dalam plot menunjukkan bahwa koefisien bobot yang digunakan dalam indeks seleksi cukup optimal dan sesuai dengan target peningkatan produktivitas kayuputih yang diharapkan dimana sifat diameter mendapatkan perolehan genetik yang besar. Hal menarik lainnya dari penelitian ini adalah bahwa walaupun seleksi dalam plot yang dilakukan merupakan seleksi fenotipik, namun mampu memberikan perolehan genetik yang relatif besar untuk kedua sifat (>10\%). Hal ini menunjukkan bahwa dalam pemuliaan kayuputih seleksi dalam plot merupakan tahapan yang penting sebagai bagian dari seleksi individu di dalam famili (within family selection), karena mampu memberikan tambahan perolehan genetik yang besar. Hasil ini juga memberikan implikasi bahwa rancangan plot uji keturunan untuk kayuputih dengan memperbanyak jumlah tree-plot dan ulangan akan menjadi langkah awal yang penting dalam optimalisasi perolehan genetik akumulatif yang akan dihasilkan.

Kesesuaian antara penjarangan seleksi dalam plot di lapangan dengan seleksi berdasarkan nilai indeks seleksi dapat dilihat dari nilai korelasi biserial. Dalam penelitian ini nilai biserial korelasi menunjukkan nilai sedang $\left(\mathrm{r}_{b}=0,59\right)$ (Tabel 4). Hal ini memberikan indikasi adanya korelasi nilai indeks tingkat sedang antara pohon terpilih di dalam plot secara fenotipik dengan yang dipilih berdasarkan nilai indeks seleksi.

Rendahnya nilai korelasi biserial pada penelitian ini diduga disebabkan oleh dua faktor. Pertama, jeda rentang waktu antara pengukuran (umur 24 bulan) dengan pelaksanaan penjarangan seleksi (umur 44 bulan) cukup lebar. Hal ini menyebabkan perbedaan kondisi pertumbuhan tanaman pada saat pengukuran dengan pada saat penjarangan sehingga menyebabkan nilai korelasi yang rendah. Kemungkinan kedua, performa pertumbuhan tanaman kayuputih sebagai dasar penjarangan seleksi dalam plot di lapangan berbeda dengan kriteria seleksi yang digunakan dalam indeks seleksi. Sebagaimana diketahui habitus tanaman kayuputih didominasi oleh performa percabangan sehingga diduga sifat ini lebih banyak digunakan sebagai dasar seleksi dalam plot di lapangan dan bukan pada sifat tinggi dan diameter yang digunakan sebagai 
dasar perhitungan indeks seleksi. Sebagai perbandingan nilai biserial korelasi pada tanaman Acacia mangium umur 40 bulan menunjukkan nilai yang hampir sama atau sedikit lebih rendah $\left(\mathrm{r}_{b}=0,51\right)$ (Handayani et al., 2017) dan pada tanaman jabon merah umur 46 bulan menunjukkan nilai yang lebih tinggi $\left(\mathrm{r}_{b}=0,89\right)$ (Surip et al., 2017).

\section{Seleksi famili}

Tahap seleksi lebih lanjut setelah seleksi dalam plot pada plot uji keturunan F2 kayuputih adalah seleksi famili. Dalam penelitian ini seleksi famili dilakukan secara simulasi menggunakan indeks seleksi berdasarkan dua kriteria seleksi dan koefisien bobot yang sama sebagaimana seleksi dalam plot, yaitu tinggi dan diameter. Perolehan genetik hasil simulasi seleksi famili menunjukkan nilai yang lebih rendah dibandingkan dengan seleksi dalam plot (Tabel 4). Namun demikian kedua sifat menunjukkan urutan besaran perolehan genetik yang sama, yaitu terbesar pada diameter dan terendah pada tinggi. Kecilnya variasi genetik (Tabel 1), diduga mendorong rendahnya perolehan genetik pada seleksi famili dibandingkan dengan seleksi dalam plot walaupun intensitas seleksi (IS) yang digunakan lebih tinggi. Seleksi dalam plot menggunakan rasio seleksi sebesar $\pm 33 \%$ (IS $=0,85$ ), sedangkan pada seleksi famili rasio seleksi sebesar $\pm 37 \%$ (IS=1).

Faktor lain yang diduga bisa menyebabkan lemahnya ekspresi genetik dari famili yang diuji adalah kemungkinan adanya interaksi famili dengan lokasi. Famili yang diuji pada plot uji keturunan F2 di Gunungkidul ini berasal dari plot uji keturunan F1 yang tumbuh di beberapa lokasi yang berbeda, yaitu Ponorogo, Gundih dan Cepu. Untuk itu observasi lebih lanjut dampak interaksi famili $\times$ lokasi ini perlu dilakukan. Hal ini disamping akan bermanfaat untuk mengetahui pola strategi penyebaran benih yang dihasilkan, juga untuk mengetahui strategi seleksi famili yang tepat pada plot uji keturunan kayuputih.
Hasil penelitian melalui dua tahap seleksi, yaitu seleksi dalam plot dan seleksi famili, juga memberikan indikasi bahwa prioritas pemilihan sifat sebagai kriteria seleksi berdasarkan nilai koefisien bobot hasil seleksi dalam plot bisa digunakan dengan baik pada seleksi famili. Hal ini sebagaimana ditunjukkan nilai positif dan konsistensi perolehan genetik sesuai target produktivitas yang diharapkan dalam pemuliaan kayuputih, yaitu keunggulan yang lebih besar pada sifat diameter. Secara akumulatif, total perolehan genetik dari dua tahap seleksi sebesar $>30 \%$ untuk diameter dan $>20 \%$ untuk tinggi (Gambar 1).

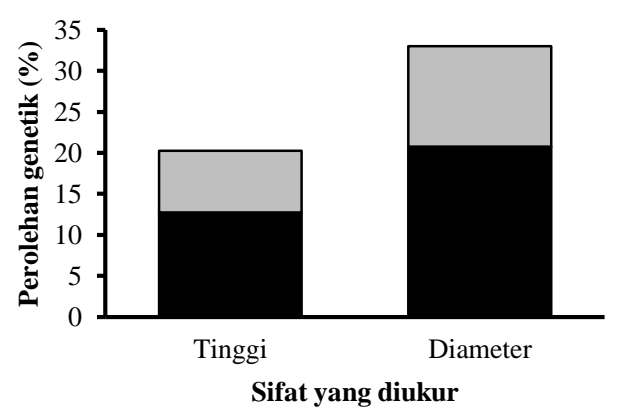

Gambar 1. Perolehan genetik pada plot uji keturunan F2 kayuputih umur 24 bulan di Gunungkidul. ( $\square$ seleksi dalam plot, $\square$ seleksi famili)

Sebagaimana diuraikan pada paragraf sebelumnya bahwa sifat diameter merupakan komponen penting dalam peningkatan produktivitas biomassa daun kayuputih. Hal ini karena dengan diameter yang besar cenderung akan menghasilkan jumlah percabangan dan jumlah daun yang lebih banyak sehingga meningkatkan produktivitas biomassa.

\section{KESIMPULAN}

Hasil penelitian menunjukkan bahwa dua tahapan seleksi pada plot uji keturunan F2 kayuputih di Gunungkidul, yaitu seleksi dalam plot dan seleksi famili, terbukti mampu memberikan perolehan genetik yang cukup besar dalam pemuliaan kayuputih (>20\%). Seleksi multi sifat menggunakan indeks seleksi dari dua kriteria seleksi, yaitu tinggi dan 
diameter, memberikan arah yang tepat dalam pencapaian target peningkatan produktivitas kayuputih, khususnya dalam peningkatan biomassa daun. Untuk itu dalam proses seleksi pada plot uji keturunan F2 kayuputih, sifat diameter perlu mendapatkan prioritas bobot yang lebih tinggi sebagai kriteria seleksi.

\section{UCAPAN TERIMA KASIH}

Ucapan terima kasih disampaikan kepada Sukijan dan Alin Maryani sebagai teknisi penelitian kayuputih dan Suroto sebagai tenaga pengawas lapangan yang telah membantu dalam pembangunan plot penelitian dan pengumpulan data. Selain itu terimakasih juga disampaikan kepada semua pihak baik secara langsung maupun tidak langsung yang telah membantu penelitian ini.

\section{DAFTAR PUSTAKA}

Chambers, P. G., \& Borralho, N. M. (1997). Importance of Survival in Short-Rotation Tree Breeding Programs. Canadian Journal of Forest Research, 27(6), 911-917.

Falconer, D. S. (1960). Introduction to Quantitatie Genetics. New York: The Ronald Press Co.

Gaspar, M. J., Louzada, J. L., Aguiar, A., \& Almeida, M. H. (2008). Genetic correlations between wood quality traits of Pinus pinaster Ait. Annals of Forest Science, 65, 1-6.

Handayani, B. R., Sunarti, S., \& Nirsatmanto, A. (2017). Selection and genetic gain in thirdgeneration seedling seed orchard of Acacia mangium. Jurnal Pemuliaan Tanaman Hutan, 11(1), 57-66. https://doi.org/10.20886/jpth.2017.11.1.57-66

Hazel, L. N. (1943). The genetic basis for constructing selection indexes. Genetics, 28, 476-490.

Kartikawati, N. K., Na'iem, M., Hardiyanto, E. B., \& Rimbawanto, A. (2013). Improvement of seed orchard management based on mating system of cajuputi trees. Indonesian Journal of Biotechnology, 18(I), 26-35.

Kartikawati, N. K., Rimbawanto, A., Susanto, M., Baskorowati, L., \& Prastyono. (2014). Budidaya dan prospek pengembangan kayuputih (Melaleuca cajuputi). (M. Na'iem, Mahfudz, \& S. B. Prabawa, Eds.). Bogor: PT
Penerbit IPB Press.

Kartikawati, N. K., \& Sumardi. (2017). Crossing potential of open pollination in cajuputi seedling seed orchard at Paliyan, Gunungkidul. Jurnal Penelitian Kehutanan Wallacea, 6(1), 41-51.

https://doi.org/http://dx.doi.org/10.18330/jwall acea.2017.vol6iss1pp41-51

Li, X., Lund, M. S., Zhang, Q., Costa, C. N., Ducrocq, V., \& Su, G. (2016). Short communication: Improving accuracy of predicting breeding values in Brazilian Holstein population by adding data from Nordic and French Holstein populations. Journal of Dairy Science, 99(6), 4574-4579. https://doi.org/10.3168/jds.2015-10609

Mawaddah, M., Mansur, I., \& Saria, L. (2012). Pertumbuhan kayuputih (Melaleuca leucadendron Linn .) dan Longkida (Nauclea orientalis Linn.) pada kondisi tergenang air asam tambang in flooded condition of acid mine water. Jurnal Silvikultur Tropika, 3(2), 71-75.

Nirsatmanto, A., \& Kurinobu, S. (2002). Trend of within-plot selection practiced in two seedling seed orchards of Acacia mangium in Indonesia. Journal of Forest Research, 7(2), 49-52.

Saputra, M. H. (2010). Evaluasi awal uji keturunan F2 kayuputih (Melaleuca cajuputi subsp. cajuputi Powell) sampai umur 6 Bulan di Playen, Gunungkidul. Universitas Gadjah Mada.

Sumardi. (2017). Taksiran parameter genetik pertumbuhan tanaman uji keturunan F2 kayuputih (Melaleuca cajuputi subsp. cajuputi) di Pulau Timor. In A. Septiasari, A. Astuti, I. N. Berlian, K. Kharismamurti, N. C. Merdekawati, \& Y. R. Alkarim (Eds.), Prosiding Semnas Biodiversitas (Vol. 6, pp. 103-106). Solo: Kelompok Studi Biodiversitas Program Studi Biologi FMIPA UNS.

Surip, Indrioko, S., Nirsatmanto, A., \& Setyaji, T. (2017). Pengaruh seleksi terhadap perolehan genetik pada uji keturunan generasi pertama (F-1) jabon merah (Anthocephalus macrophyllus Roxb. Havil.) di Wonogiri. Jurnal Pemuliaan Tanaman Hutan, 11(1), 183-194.

Yamada, Y. (1977). Evaluation of the Culling Variate Used by Breeders in Actual Selection. Genetic, 86, 885-889.

Zobel, B., \& Talbert, J. (1984). Applied forest tree improvement. New York, Brisbane, Toronto, Singapore: John Willey and Sons. 
Jurnal Pemuliaan Tanaman Hutan

Vol. 12 No. 1, Juni 2018, p. 65 - 73 